\title{
Evaluation of bedbath in critically ill patients: impact of water temperature on the pulse oximetry variation
}

\author{
AVALIAÇÃO DO BANHO NO LEITO DE DOENTES CRÍTICOS: IMPACTO DA TEMPERATURA \\ DA ÁGUA NA VARIAÇÃO DA OXIMETRIA DE PULSO
}

EVALUACIÓN DEL DO BAÑO EN EL LECHO DEL ENFERMO CRÍTICO: IMPACTO DE LA TEMPERATURA DEL AGUA EN LA VARIACIÓN DE LA OXIMETRÍA DE PULSO

\section{Aretha Pereira de Oliveira ${ }^{1}$, Dalmo Valério Machado de Lima ${ }^{2}$}

\begin{abstract}
This is a participant study, quasi-experimental, of a before and after type. A quantitative approach of biophysiological measures was used, represented by the saturation of oxygen measured by pulse oximeter $\left(\mathrm{SpO}_{2}\right)$, and recorded on three occasions: before, during and after the bedbath in critically ill patients hospitalized at the ICU of a University Hospital in Brazil. Objective: to compare the $\mathrm{SpO}_{2}$ in various stages of the bath, with and without control of water temperature. Data collection was performed between December 2007 and April 2008 on a convenience sample consisting of 30 patients aged over 18 who had classification in TISS28 from level II. Results show that water temperature control means a lower variation of $\mathrm{SpO}_{2}(p<0.05)$. No marked differences in variation of saturation between men and women or between age groups were established. In conclusion, heated and constant water temperature during the bedbath is able to minimize the fall of $\mathrm{SpO}_{2}$ that occurs while handling patients during procedures.
\end{abstract}

\section{KEY WORDS}

Oximetria.

Banhos.

Unidades de Terapia Intensiva.

\section{RESUMO}

Estudo participante, quase-experimental, tipo antes e depois, utilizando abordagem quantitativa de medidas biofisiológicas, representadas pela saturação de oxigênio, medida pelo oxímetro de pulso $\left(\mathrm{SpO}_{2}\right)$ e registrada em três momentos: antes, durante e após o banho no leito do doente crítico internado em UTI de um hospital universitário no Brasil. Objetivou-se comparar a $\mathrm{SpO}_{2}$ em vários estágios do banho, com e sem controle da temperatura da água. Amostra de conveniência coletada entre dezembro de 2007 e abril de 2008, composta por 30 pacientes com idade superior a 18 anos, com classificação no TISS-28 a partir do nível II. Os resultados mostraram que a temperatura da água controlada reflete numa menor variação da $\mathrm{SpO}_{2}$ ( $p$ $<0,05)$. Não foram estabelecidas diferenças nítidas na variação da saturação entre homens e mulheres ou entre os grupos etários. Concluiu-se que a temperatura da água aquecida e constante durante o banho no leito é capaz de minimizar a queda da $\mathrm{SpO}_{2}$ durante a manipulação do paciente para a realização do procedimento.

\section{DESCRITORES}

Oximetry.

Baths.

Intensive Care Units.

\section{RESUMEN}

Estudio participativo, cuasi-experimental, tipo antes y después, que utilizó abordaje cualitativo de medidas biofisiológicas, representadas por la saturación de oxígeno medida por el oxímetro de pulso $\left(\mathrm{SpO}_{2}\right)$, registrada en tres momentos: antes, durante y después de un baño en el lecho del enfermo crítico internado en UTI de un hospital universitario en Brasil. Objetivo: comparar la $\mathrm{SpO}_{2}$ en diferentes momentos del baño, con y sin control de temperatura de agua. Muestra de conveniencia recolectada entre diciembre de 2007 y abril de 2008 , compuesta por 30 pacientes con edad superior a 18 años con clasificación en TISS-28 a partir de nivel II. Los resultados muestran que la temperatura de agua controlada determina una menor variación en la $\mathrm{SpO}_{2}(p<0,05)$. No fueron establecidas nítidas diferencias en la variación de saturación entre hombres y mujeres o entre los grupos etarios. Se concluyó en que la temperatura del agua precalentada y constante durante el baño en el lecho es capaz de minimizar la caída de la $\mathrm{SpO}_{2}$ que ocurre durante la manipulación del paciente para la realización del procedimiento.

\author{
DESCRIPTORES \\ Oximetría. \\ Baños. \\ Unidades de Terapia Intensiva.
}

${ }^{1}$ Nursing student, Universidade Federal Fluminense. Niterói, RJ, Brazil. enfermeira_aretha@hotmail.com 22RN, MSN, PhD in Nursing, Universidade Federal Fluminense. Adjunct Professor, Department of Medical-Surgical Nursing, Group on Nursing Care Systemization (GESAE), Graduate Program in Cardiovascular Sciences, Universidade Federal Fluminense. Niterói, RJ, Brazil. dalmomachado@enf.uff.br

$\begin{array}{cl}\text { Rev Esc Enferm USP } & \text { Recebido: 05/18/2009 } \\ \text { 2010; 44(4):1034-40 } & \text { Aprovado: 03/10/2010 }\end{array}$




\section{INTRODUCTION}

The hospital environment aims at care for people with health disorders, who have specific needs. This service is delivered by professionals in various sectors within specific health units. Seriously ill patients need more specialized environments, which can guarantee the preservation of vital organ functioning and maintained clinical stability.

Intensive Care Units (ICUs) are sectors that have special equipment and trained people to attend to the needs of seriously ill or risk patients who require uninterrupted medical and nursing care ${ }^{(1)}$. Besides these resources, there are standards relating to the physical environment that have to be met to ensure appropriate care for these people. Regarding environmental temperature, Brazilian legislation demands that temperature be controlled between 21 and $24^{\circ} \mathrm{C}$, with relative humidity between 40 and $60 \%{ }^{(1)}$. It is also important to note that an ICU is not restricted to the provision of lifesupport services, and that patients' needs for comfort and welfare should be prioritized.

In daily nursing care, however, some techniques are clearly relegated to the background. The explanation may be the fact that various professionals consider them less important $^{(2)}$, and thus delegate them to other team members. These techniques include the bed bath, a practice that involves complex expertise and that, if held in inappropriate conditions, may cause variations in patients' clinical state, whose implications can cause instability and risks to the patients.

In a review of scientific literature, it was observed that bed bathing is a matter of controversy among nurses. In a study on nursing aspects professionals recovered in health care, the aspect professionals most important was the bath, mentioned by $79.5 \%$ of the 88 participants in the study ${ }^{(3)}$. However, in another study with 32 nurses in Rio de Janeiro (Brazil), which sought the meaning of the art of bed bath for nurses, statements that characterized the bath as an exhausting, manual and routine work were expressed, strengthening the idea of a non-prestigious procedure ${ }^{(2)}$.

In the context of critical patients, any changes that may act directly or indirectly on the patient, even if small, can cause instability and worsening of the general state, since the act of turning upwards during the full bed bath, in combination with nursing interventions, may increase the body's oxygen demand ${ }^{(4)}$. Moreover, it has been suggested that the tremors caused by the variation in water temperature cause variations in venous mixed oxygen saturation $\left(\mathrm{SvO}_{2}\right)$, leading to a greater energy need ${ }^{(5)}$. Despite the lack of a standardized guideline for bed baths to critical patients, a recent systematic review demonstrated that these patients seem to benefit from some actions: avoid the bath within less than $4 \mathrm{~h}$ after cardiac surgery; try to be brief when positioning the patient in lateral decubitus; complete the bath within 20 minutes $^{(6)}$. Therefore, efficient planning of the procedure is needed, considering duration, water temperature and changes in the patient's position.

Thus, the purpose of this study, carried out at the ICU of a university hospital, was to confirm the following assumption regarding the bed bath, an essential nursing technique: controlling water temperature is more effective than not controlling the temperature during the bed bath by the nursing staff in order to reduce the average change in tissue oxygenation, measured by a pulse oximeter, in critical patients.

\section{OBJECTIVES}

The aims of the study were to measure the average change in tissue oxygenation through the pulse oximeter during the bed bath of critical patients, with and without the control of water temperature; to compare this change in tissue oxygenation; to evaluate the effects of water temperature on the bed bath of critically ill patients.

\section{METHOD}

Participant, quasi-experimental, beforeand-after study in which the quantitative approach of biophysiological measures was used, represented by oxygen saturation through the pulse oximeter $\left(\mathrm{SpO}_{2}\right)$ measure, recorded in three blocks: before, during and after the bed bath of critical patients hospitalized at the ICU of a university hospital in Brazil.

A convenience sample of critical patients was recruited, set at 30 individuals through a sample size calculation. Patients were selected through the following eligibility criteria: patients of both sexes, aged over 18 years, admitted to the ICU, which were in monitoring of oxygen saturation by a pulse oximeter, classified as level II in the Therapeutic Interventions Score System-28 (TISS-28) and whose family agreed to sign the Informed Consent. TISS-28 is a pioneer system to classify patient severity and the nursing workload, created by Cullen in $1974^{(7)}$.

In compliance with Resolution 196/96 by the Brazilian National Health Council, this study was submitted to a Research Ethics Committee for evaluation and approved under process number 0148.258.000-07. This Resolution contemplates all ethical standards set forth in the Helsinki Declaration of 1975. An Informed Consent Term was elaborated with data to identify the patient, identification of those responsible for the work, the research aims, the procedures for participating and the benefits that can be obtained.

To carry out this study, besides the material needed for the bed bath, an ICEL HT- $208^{\circledR}$ thermo-hygrometer and its 
own thermometer unit were used, which permits checking the water, verifying environmental temperature, relative humidity and water temperature; water temperature was maintained through a Logen Scientific ${ }^{\circ}$ Hot Plate, lent from the Analytical Chemistry Department of a federal university.

One of the researchers collected all data through observation and recording of variations in $\mathrm{SpO}_{2}$ and water temperature. These data were recorded every two minutes in a form containing: patient identification data, total TISS28 score, water temperature, environmental temperature and relative humidity before, during and after the bed bath. In line with a thesis, the periods before and after the bath were set at 15 minutes before and after the procedure, respectively ${ }^{(8)}$. Water temperature was measured and recorded from the beginning of the bath until the end of the procedure.

To maintain uniformity in collected measures, the pulse oximeter was placed on the index finger of the right hand of all selected patients. A glove was used on this hand to avoid interference from illumination in the ideal functioning of the oximeter, and to prevent its contact with water, which could damage it. Each patient was submitted to a control bath, carried out in normal conditions, and experimental bath, in with the water temperature was kept constant and heated to $40^{\circ} \mathrm{C}^{(9)}$. The collected information was included in a spreadsheet for statistical analysis.

It is important to assure that the measurement and selection risks were minimized so as not to interfere in the study result. The former was controlled by using the same instrument in the two measurements performed on each patient; the second was avoided through the use of a before and after research design.

Descriptive statistics included: media, median, variance, standard deviation and variation coefficient, Pearson's coefficient and percentage difference.

Statistical inference included a parametric test of hypotheses. The test chosen was student's t-test, appropriate to compare paired samples of equal variances. To carry out this test, the statistical package NCSS / PASS 2000 Dawson Edition was used, which permits one- and twotailed testing, according to the alternative hypothesis formulated. The confidence interval used was set at $95 \%$, and the level of significance $(\alpha)$ was previously fixed at 0.05 .

\section{RESULTS AND DISCUSSION}

The sample comprised $50 \%$ of male patients, with an average age of $50 \pm 14$ years ( $C V=33.5 \%)$, mainly in TISS Class II (93.33\%). It is important to stress that patients within TISS Class III presented the scores near the minimum necessary for this classification (35 points), which leaves them in conditions similar to those in Class II.

The analysis of Figure 1 shows that the median and the third quartile (Q3) for the sexes are very close, despite the greater dispersion presented by males, which indicates greater variation of age. The main intergroup difference is found in the first quartile (Q1), showing that the first $25 \%$ of the male sample are younger than those in the female sample.

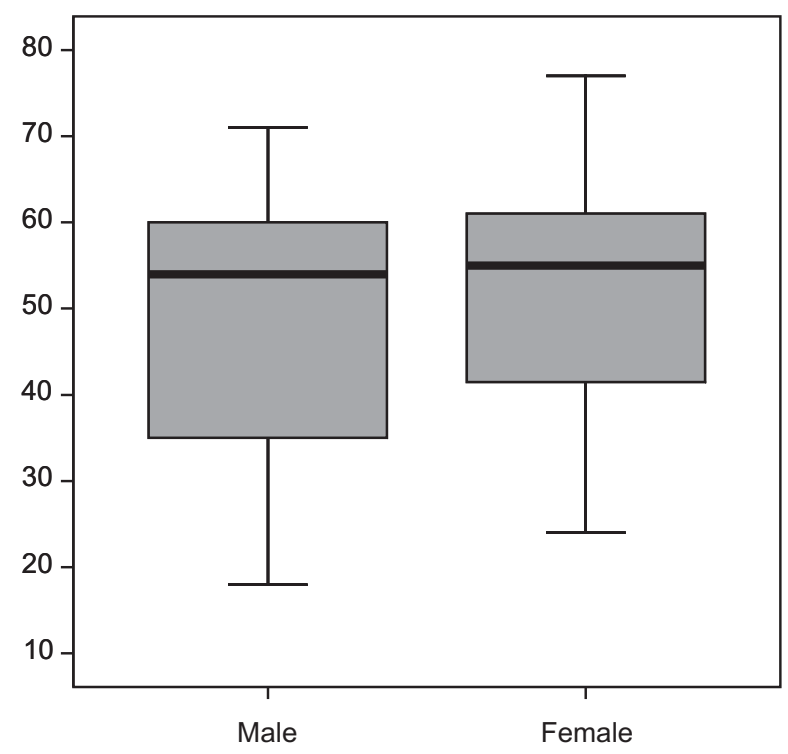

Source: ICU of Hospital Universitário Antônio Pedro, Brazil / Dec 2007 - Apr 2008

Figure 1 - Gender and age of patients to assess $\mathrm{SpO}_{2}$ during the bed bath

Considering all patients' dependence on ventilation support, examining the fraction of inspired oxygen $\left(\mathrm{FiO}_{2}\right)$ offered to each patient during the control and trial bath is important. To illustrate this, $\mathrm{FiO}_{2}$ was compared between both baths, and their percentage differences observed during 14 observations revealed higher $\mathrm{FiO}_{2}$ during trial baths.

$\mathrm{FiO}_{2}$ is a variable that can interfere directly in saturation. Thus, the existence of linear correlation between $\mathrm{FiO}_{2}$ and $\mathrm{SpO}_{2}$ during the pre-bath was assessed through Pearson's coefficient. The results were $r=-0.22$ in control and $r=-0.26$ in experiment, which means a weak negative linear correlation ${ }^{(10)}$. It is important to note that $r$-values in control and experiment are very close, indicating regularity in ventilation patterns on both occasions.

During the observation of baths, it was understood that, in general, average $\mathrm{SpO}_{2}$ decreased when comparing the moments before and after bathing, both in control and experiment. However, it should be noted that the change occurred in the experiment was lower than that observed in control. Thus, it can be assumes that the variation in tissue oxygenation depends on factors other than water temperature. These factors can be related to patient movement by the nursing staff, exposure to low temperatures characteristics of the ICU, massaging the skin, placing the patient in specific positions, sedation, state of alertness or use of vasoactive drugs. All these are connected to possible interference in $\mathrm{SpO}_{2}$, because they could represent a cardiovascular commitment, increasing 
the demand for oxygen in tissues, or cause negative impacts on ventilation mechanisms.

Figure 2 shows average $\mathrm{SpO}_{2}$ behavior before, during and after control and experiment baths. This time evolution shows a drop in $\mathrm{SpO}_{2}$ during the procedure, which is smaller during the experiment. In the post-bath control, saturation increases, returning to values close to the initial experiment, and also an important recovery in control.

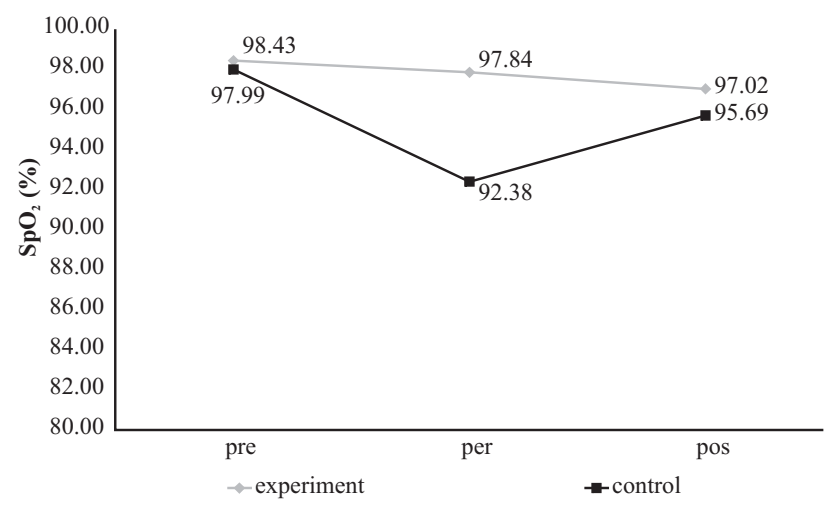

Source: ICU of Hospital Universitário Antônio Pedro, Brazil / Dec 2007 - Apr 2008

Figure 2 - Comparison between mean $\mathrm{SpO}_{2}$ before (pre), during (per) and after (pos) control and experiment baths in patients undergoing $\mathrm{SpO}_{2}$ evaluation during the bed bath

Analyzing the variation in the $\mathrm{SpO}_{2}$ intervals before and during the control and experiment, it is observed that, in control, there is a sharp drop in $\mathrm{SpO}_{2}$ during the procedure when compared to the moment before the technique. In the experiment, however, this reduction was less prominent. A comparison between percentage differences before and during the control and experiment baths shows that $87 \%$ of patients experienced less variation in oxygen saturation during the bath intervention. It is important to emphasize that seven patients showed increased average $\mathrm{SpO}_{2}$ during the experiment bath, while one patient did not show any variation.

All patients experienced decline in average $\mathrm{SpO}_{2}$ during the control bath. This data shows a larger variation in usual conditions than during the experiment, which does not necessarily mean that individuals became more unstable. Exemplifying this, it was observed in a previous study that small changes in oxy-hemodynamic parameters during the bed bath do not necessarily mean clinical instability ${ }^{(5)}$. However, eleven patients (36.6\%) showed average $\mathrm{SpO}_{2}$ during the control bath below the $92 \%$ recommended as the normal limit ${ }^{(11)}$. In contrast, only two patients presented a similar result during the experiment. Besides, one of then showed a small increase in average $\mathrm{SpO}_{2}$ when compared to pre-bath.

Similarly, in the intervals before and after the bath, when comparing the percentage differences between control and experiment, seven patients (23.3\%) experienced less variation in the control; one patient presented the same percentage difference in control and experiment. It is evident that, in the control, there is an increase in average $\mathrm{SpO}_{2}$, and seven patients showed a better saturation in this procedure when compared to the experiment. It shows that there are other factors interfering in saturation variation.

It is important to stress that the patient who showed the most significant difference between the procedures was very agitated and, while changing sheets during the experimental bath, he was accidentally extubated. During the first four minutes of post-bath, a manual resuscitation bag was used to ensure ventilation. In the interval between five and eight minutes, a new intubation was performed. This fact explains the reason for an individual variation as highlighted when compared to the sample in general.

Another important event was one patient who moved, though sedated (Ramsay I), and turned during the whole experiment bath procedure which, as the literature says, is one of the factors indicating low detection because it can promote distortions in the signals sent ${ }^{(11)}$. As for the control bath, the level of sedation was higher (Ramsay IV) and the patient did not interfere in the procedure. Regarding the remainder, we can infer that there is physiological variability intrinsic to each patient that permitted better adaptation to situations they were submitted to during the bath. This may be due to alveolar lung opening in areas previously not aired, consequently increasing the ventilationperfusion ratio.

As the sample contains $50 \%$ men, it is important to compare $\mathrm{SpO}_{2}$ behavior during the control and experiment bath between the sexes. For this purpose, average percentage differences in $\mathrm{SpO}_{2}$ were calculated between both sexes for the pre-per and pre-pos bath intervals.

The analysis of Table 1 identifies very similar behavior between men and women during the pre-per interval in control. This reinforces the assessments of a previous study ${ }^{(4)}$, in which the differences in transcutaneous oxygen pressure measurement between genders during nursing activities, among them the bed bath, were not statistically or clinically significant. In the experiment, a significant reduction in saturation variation occurs in the two cases. It can be noted though that this change in women was still lower when compared to men. In the pre-post interval, men showed almost the same variation in control and experiment. In the experiment, women displayed a lower range and values closer to the pre-per interval. In this study, no significant differences between the sexes were found, showing that probably, lower rates of hemoglobin and hematocrit in women ${ }^{(12)}$, which involve the transportation of a lower oxygen volume, are not sufficient to cause harmful changes in women's $\mathrm{SpO}_{2}$. On the contrary, they reacted better during the pre-per experiment, with a less prominent change. 
Table 1 - Comparison between the average percentage differences between the sexes in $\mathrm{SpO}_{2}$ intervals PRE-PER and PRE-POST of control and experiment baths for patients undergoing evaluation for the bed bath

\begin{tabular}{lcccc}
\hline \multirow{2}{*}{ Sex } & \multicolumn{2}{c}{ Control } & \multicolumn{2}{c}{ Experiment } \\
\cline { 2 - 5 } & PRE-PER & PRE-POST & PRE-PER & PRE-POST \\
\hline Female & -5.96 & -1.41 & -0.26 & -0.39 \\
Male & -5.04 & -2.43 & -0.84 & -2.46 \\
\hline
\end{tabular}

Source: ICU of Hospital Universitário Antônio Pedro, Brazil / Dec 2007 - Apr 2008

Taking into account the different ages of patients screened, the analysis of Table 2 shows very similar behavior in the preper interval, both in control and experiment. The age groups were divided between 18 and 50 and 52 to 77 years, because the average age found was 50 years. Like in previous cases, a much less pronounced drop in $\mathrm{SpO}_{2}$ occurs during the experiment, with variation kept close to zero between the pre and per bath periods. In pre-post intervals, it is observed that the two groups showed better control, but the younger group showed greater variation than the older. In the experiment, the younger group showed a drop in $\mathrm{SpO}_{2}$; in contrast, the older group showed considerable improvement, increasing saturation, and was the only group to achieve continuous improvement in the pre-post experiment interval.

Table 2 - Comparison between the average percentage differences in the $\mathrm{SpO}_{2}$ intervals PRE-PER and PRE-POST baths of control and experiment according to the age of the patient undergoing evaluation during the bed bath

\begin{tabular}{lcccc}
\hline \multirow{2}{*}{ Age } & \multicolumn{2}{c}{ Control } & \multicolumn{2}{c}{ Experiment } \\
\cline { 2 - 5 } & PRE-PER & PRE-POST & PRE-PER & PRE-POST \\
\hline $\mathbf{1 8 - 5 0}$ & -4.47 & -1.52 & -0.37 & -2.86 \\
$\mathbf{5 2 - 7 7}$ & -5.31 & -2.23 & -0.84 & -0.73 \\
\hline
\end{tabular}

Source: ICU of Hospital Universitário Antônio Pedro, Brazil / Dec 2007 - Apr 2008

This observation shows that, contrary to what might be suggested by cardiovascular, respiratory and skin aspects, inherent to the process of getting older ${ }^{(13)}$, old patients hardly changed during the bed bath. Clearly, it appears that, during the experiment, variations remained close to zero, which would represent no change between the pre and per bath periods, and therefore less oxy-hemodynamic variability.
It is necessary to emphasize that hemoglobin saturation as measured by the pulse oximeter does not indicate that the oxygen required by cells of different organic tissues is being properly distributed to them, as pulse oximetry determines the percentage of hemoglobin that is saturated by oxygen ${ }^{(14)}$. In this sense, as an example, septicemia can be observed. Sepsis can be defined as a response of the host to the presence of microorganisms in previously sterile tissues, characterized by the dysfunction of noble organs $^{(15)}$. It is known that septic patients have trouble to metabolize the oxygen, even if at normal levels. It is suggested that one of the mechanisms likely to cause this amendment is an abnormality in the function of red blood cells, increasing the affinity of hemoglobin with $\mathrm{O}_{2}$, reducing oxygen release to tissues ${ }^{(11)}$. Thus, in situations like sepsis, even if the patient presents $\mathrm{SpO}_{2}$ levels within the normal range, he must be assessed and monitored, at risk of developing severe hypoxia.

Due to the reduced quantity of patients included in Class III, a comparative analysis between the classifications was not possible, as this sample was not representative and, possibly would not reflect the real conditions patients with this degree of invasion are submitted to. Thus, all patients were considered as having similar levels of invasiveness.

It is important to emphasize that, while the TISS-28 is important and widely diffused in quantifying nursing work, it values screening through artifacts that are in continuous disuse, such as the Swan-Ganz catheter, the item that determines the highest scores. The system went through two major modifications in 1983 and 1996, with a view to greater measurement efficiency ${ }^{(16)}$. It may be necessary to perform a new adaptation of the score, replacing certain practices by others, such as using tubes, or attributing higher scores to some interventions already described, since the way it is presented today cannot faithfully characterize the needs of each patient.

To see if the variation found was statistically significant, a test of hypotheses was conducted. The test chosen was student's t-test, appropriate for the comparison between paired samples of equal variances, such as the present study, which has two sets of data for each patient. The level of significance $(\alpha)$ was 0.05 . The results are shown briefly in Table 3.

Table 3 - Student's t-test one-tailed for testing the hypothesis proposed in various stages of the bed bath, with $\alpha=0.05$

\begin{tabular}{lcccc}
\hline Phases & t-value & p-value & $\boldsymbol{\alpha}$ & Decision \\
\hline PRE-PER CTRL x PRE-PER EXP & -5.8706 & 0.000001 & 0.05 & Rejects $\mathrm{H}_{0}$ \\
PRE-POST CTRL x PRE-POST EXP & -0.9093 & 0.185352 & 0.05 & Does not reject $\mathrm{H}_{0}$ \\
\hline
\end{tabular}

Source: ICU of Hospital Universitário Antônio Pedro, Brazil / Dec 2007 - Apr 2008

The results showed that, when comparing the pre-per interval in control and experiment at $p<\alpha$, a statistically significant difference was found between the average percentage decrease in $\mathrm{SpO}_{2}$ when patients are subject to a bed bath with varying water temperature, and the decrease when the water temperature is constant. These data imply the rejection of $\mathrm{H}_{0^{\prime}}$ which means, in other words, that patients exposed to constant water temperature tend to maintain the highest $\mathrm{SpO}_{2}$. 
However, when comparing the pre-post interval at $p>\alpha$, which indicates that there are no statistically significant differences between the average percentage decrease in $\mathrm{SpO}_{2}$ after the bath. This information permits inferring that patients can recover from the decreases suffered during the bed bath.

In this sense, it is important to note that the critical pvalue in this study is 0.061 . Critical $p$ can be defined as the first $p$-value, amending the decision established by the test. In other words, it is the p-value that would result in the nonrejection of $\mathrm{H}_{0}$. When comparing the $\mathrm{p}$-value found in different stages of the bath with the critical p-value, in all ranges, the $p$-value is markedly lower than the critical $p$. This permits saying that, possibly, even in case of interference of variables involved, this does not amend to the research result, confirming the valid rejection of the null hypothesis.

\section{CONCLUSION}

After the presentation and discussion of results, it can be said that the objectives were fully achieved. The comparison between the average change in $\mathrm{SpO}_{2}$ during the bath with and without control of water temperature showed a positive impact when water temperature is kept stable during the procedure, illustrating the appropriateness of the analysis.

It is clear that the way the bath is carried out is likely to cause instability in the clinical situation of critical patients. The water temperature, an important parameter that does not receive due attention, can cause major changes in patient stability, impairing the recovery process. It is important, therefore, to effectively monitor temperature changes, especially in critical care units. For this purpose, devices can be used that function as thermostats to guarantee the maintenance of adequate water temperature throughout the bath period. Technology needs to be improved and improve nursing care, aiming for the recovery of patients who require continuous care.

\section{REFERENCES}

1. Brasil. Ministério da Saúde. Agência Nacional de Vigilância Sanitária. Resolução RDC n.50, de 21 de fevereiro de 2002. Regulamento técnico para o planejamento, programação, elaboração e avaliação de projetos físicos de estabelecimentos assistenciais de saúde [legislação na Internet]. Brasília; 2002. [citado 2007 abr. 18]. Disponível em: http://anvisa.gov.br/legis/ resol/2002/50_02rdc.pdf

2. Figueiredo NMA, Carvalho V, Tyrrel MAR. (Re)lembrando Elvira de Felice: gestos e falas de enfermeiras sobre o banho no leito, uma técnica/tecnologia de enfermagem. Esc Anna Nery Rev Enferm. 2006;10(1):18-28.

3. Oliveira EA, Garcia TR, Sá LD. Aspectos valorizados por profissionais de enfermagem na higiene corporal pessoal e na higiene corporal do paciente. Rev Bras Enferm. 2003;56(5):479-83.
Heated and constant water temperature during the bed bath reduced the normal range of $\mathrm{SpO}_{2}$ that occurs during patient manipulation. Therefore, there is a need to return to the basic precepts of the technique, which is not being developed as specified, with a view to improving the care provided to ICU patients, in an environment where various stressors and risks appear.

The results ratify the assumptions that controlled water temperature favors the maintenance of patient stability and may positively influence the timing of recovery, which is positive for individuals, the community and institutions. As the bath is an important therapeutic procedure and, at the same time, little appreciated and discussed, this evaluation permits asserting that the best way to achieve the full bed bath is to identify factors inherent in that care act that contribute to the maintenance of patients' oxyhemodynamic stability.

Frequent discussion and review of nursing techniques and basic tasks is needed to provide improvements and advances, able to contribute to a more qualified care, allowing the team to deliver scientifically sound care.

The analysis of the impact of water temperature on $\mathrm{SpO}_{2}$ variation is extremely relevant, because it permits a critical and reflexive evaluation of the technique. Thus, possible adverse effects of this practice can be minimized, providing high-quality care to critical patients. In addition, some patients' $\mathrm{SpO}_{2}$ could be improved, which could enhance their recovery process.

There were some limitations in this study. The most important one is that it was impossible to perform a blind study. Also, selected patients were submitted to a low degree of invasiveness, and it was not possible to reflect on variations that can occur with very ill patients, submitted to a lot of invasive procedures.

4. Verderber A, Gallagher KJ, Severino R. The effect of nursing interventions on transcutaneous oxygen and carbon dioxide tensions. West J Nurs Res. 1995;17(1):76-90.

5. Lima DVM. O banho no leito na Unidade de Terapia Intensiva (UTI): conceitos e preconceitos (a ciência subsidiando um cuidado de enfermagem) [dissertação]. Rio de Janeiro: Escola de Enfermagem Alfredo Pinto, Universidade Federal do Estado do Rio de Janeiro; 2002.

6. Lima DVM. Repercussões oxi-hemodinâmicas do banho no paciente adulto internado em estado crítico: evidências pela revisão sistemática de literatura [tese]. São Paulo: Escola de Enfermagem, Universidade de São Paulo; 2009. 
7. Grillo KP, Sousa RMC, Miyadahira AMK, Cruz DALM, Vattimo MFF, Kimura M, et al. Therapeutic Intervention Scoring System28 (TISS-28): diretrizes para aplicação. Rev Esc Enferm USP. 2005;39(2):229-33.

8. Barbato MG. Estudo das alterações dos sinais vitais e eletrocardiografia, secundárias ao banho no leito, em portadores de insuficiência coronária aguda [tese livre-docência]. Rio de Janeiro: Escola de Enfermagem Anna Nery, Universidade Federal do Rio de Janeiro; 1977.

9. Souza EDF. Novo manual de enfermagem. 6a ed. Rio de Janeiro: Cultura Médica; 1976.

10. Pagano M, Gauvreau K. Principles of biostatistics. 2nd ed. Pacific Grove (CA): Duxbury; 2000.

11. Darovic GO. Hemodynamic monitoring: invasive and noninvasive clinical application. 3rd ed. Philadelphia: Saunders; 2002.
12. Guyton AC, Hall JE. Tratado de fisiologia médica. 10ª ed. Rio de Janeiro: Guanabara Koogan; 2002.

13. Smeltzer SC, Bare BG. Brunner \& Suddarth: tratado de enfermagem médico-cirúrgica. $10^{\mathrm{a}}$ ed. Rio de Janeiro: Guanabara Koogan; 2005.

14. Woods SL, Froelicher ESS, Motzer SU. Enfermagem em cardiologia. 4a ed. São Paulo: Manole; 2005.

15. Silva E, Passos RDH, Ferri MB, Figueiredo LFP. Sepsis: from bench to bedside. Clinics. 2008; 63(1):110-20.

16. Balsanelli AP, Zanei SSSV, Whitaker IY. Carga de trabalho de enfermagem e sua relação com a gravidade dos pacientes cirúrgicos em UTI. Acta Paul Enferm. 2006;19(1):16-20. 